\title{
МОРФОМЕТРИЧНІ ПОКАЗНИКИ СЕРЦЯ У ГОСТРОМУ ПЕРІОДІ ЛАКУНАРНОГО ІнсультУ
}

\author{
○H. P. Coxop \\ ДВНЗ «Тернопільський державний медичний університетімені I. Я. Горбачевського МОЗ України» \\ РЕЗЮМЕ. У 122 хворих з лакунарним інсультом (ЛІ) проведено визначення морфометричних показників серця та \\ параметрів центрально гемодинаміки. Встановлено, що для ЛІ характерна наявність помірно та виражено гіпертрофі \\ ЛШ (у 89,3 \%), патологічного ремоделювання ЛШ (у 86,1\%) переважно у вигляді концентрично гіпертрофі ЛШ - \\ (у 76,6 \%), діастолічна дисфункція ЛШ за гіпертрофічним типом (у 86,9%) хворих. Спостерігалася залежність \\ морфометричних показників від тяжкості ЛІ: при тяжких ЛІ виявлено достовірно більший ступінь гіпертрофі ЛШ, \\ більші розміри ЛП та достовірно нижчу ФВ та СІ, порівняно з пацієнтами із легким та середньотяжким ЛІ. \\ КЛЮЧОВІ СЛОВА: лакунарний інсульт, морфометричні показники серця, центральна гемодинаміка.
}

Вступ. Однією з головних причин різних підтипів II $€$ артеріальна гіпертензія (АГ), найважливішим патологічним наслідком яко $є$ гіпертрофія лівого шлуночка (ЛШ) і судинно стінки у відповідь на збільшення навантаження і розтягнення. При підвищенні артеріального тиску (АТ) розвивається клітинна проліферативна реакція, причому чим вищий АТ i триваліша АГ, тим більше виражена гіпертрофія міокарда і стінки артерій [2]. АГ та лакунарний інсульт (ЛІ) тісно пов'язані між собою. АГ при ЛІ спричиняє розвиток ліпогіалінозу - дегенеративно дезорганізаці дистальних відділів сегментів пенетруючих артерій, що проявляється потовщенням судинно стінки, локальною дилатацією $з$ наступним руйнуванням та формуванням інфаркту [6]. Було виявлено дуже міцний зв'язок гіпертензі та ЛІ проти нелакунарного інсульту (RR 1,11; $95 \%$ Cl від 1,04 до 1,19) [4]. Гемодинамічні чинники, як відомо, грають значну роль при гострому ЛІ [7]. В дослідженні C. Sierra і співавт. був виявлений тісний кореляційний зв'язок між прихованими (які виявлялися лише за даними МРТ) ураженнями мозку та концентричною гіпертрофією ЛШ у старших людей [8]. Проте, не зважаючи на те, що гемодинамічні чинники можуть передбачити тяжкість ॥ та його прогноз, роль порушених показників центрально гемодинаміки при ЛІ не до кінця 3'ясована [3].

Мета роботи: вивчення особливостей морфометричних показників серця та параметрів центрально гемодинаміки у гострому періоді ЛІ.

Матеріали і методи дослідження. До обстеження було включено 122 пацієнти з встановленим діагнозом ЛІ відповідно до критері в TOAST: наявність лакунарного вогнища на МРТ та наявність у клінічній картині одного з п'яти типових синдромів лакунарного ураження. ЛІ розцінювали як вогнище, гіперінтенсивне у Т2 режимі, розмірами не більше 15 мм, розташоване у підкіркових відділах півкуль мозку або в стовбурі мозку. Вік хворих склав від 45 до 70 років (в середньому $(57,4 \pm 1,6)$ р.): хворих віком $45-60$ р. було $65(53,3 \%)$, старше 60 р. - 57 (46,7\%). Чоловіків було 71 $(58,2 \%)$, жінок - $51(41,8 \%)$. ЛІ у каротидному басейні діагностовано у $114(93,4 \%)$, у вертебробазилярному басейні - у $8(6,6 \%)$ хворих.

У $116(95,1 \%)$ обстежених хворих була виявлена АГ. Серед іншо супутньо патологі спостерігались: цукровий діабет - у 32 (25,5\%), IXC - у 46 $(37,7 \%)$, аритмія - у $5(4,1 \%)$ хворих. Серед факторів ризику було виявлено: атерогенну дисліпопроте немію - у 23 (27,4\%), куріння - у $24(28,6 \%)$, аліментарне ожиріння - у $21(17,2 \%)$ хворих. АТ в дебюті у всіх хворих з ЛІ був підвищеним. САТ коливався від 150 до 250 мм рт. ст. і склав в середньому $(190,49 \pm 3,64)$ мм рт. ст. ДАТ коливався від 80 до 160 мм рт. ст., в середньому $(103,66 \pm 2,03)$ мм рт. ст.

Розвиток вогнищевих неврологічних симптомів у $69(82,1 \%)$ хворих характеризувався гострим початком. У $82(67,2 \%)$ пацієнтів з ЛІ спостерігалось поступове зростання вираженості симптомів впродовж декількох годин або х флуктуація. В обстежених хворих не виявлено порушення свідомості, головного болю, розладів дихання, порушення полів зору та інших загальномозкових симптомів, які б свідчили про набряк мозку.

Проведено аналіз частоти типових лакунарних синдромів в обстежених хворих, що спостерігалися у $116(95,1 \%)$ хворих. Моторний варіант ЛІ зустрічався у $32(26,2 \%)$, сенсорний - у $21(17,2 \%)$ хворого. Синдром атаксичного геміпарезу зустрічався значно рідше - у 8 (6,7 \%) хворих. У 24 (19,8\%) хворих клінічний симптомокомплекс було розцінено як синдром дизартрі - незграбно руки та у 6 $(4,9 \%)$ пацієнтів клінічні прояви ЛІ не вкладалися в жоден з основних типів.

Тяжкість стану хворих та ступінь неврологічного дефіциту визначали на 1-шу добу за шкалою NIHSS. У відповідності до шкали NIHSS у 45 (36,9 \%) хворих виявлено легкий ЛІ, у $70(57,4 \%)-$ ЛІ середнього ступеня тяжкості та в $7(5,7 \%)$ - тяжкий ЛІ. Тяжкість інсульту коливалася від 2 до 14 балів і в середньому становила $(6,72 \pm 0,70)$ бали. Достовірно вищу важкість ЛІ виявлено у пацієнтів молод- 
Оеляди літератури, ориаінальні дослідження, поеляд на проблему

шо віково групи - $(7,34 \pm 0,52)$ бали, порівняно з Хворими старше 60 р. - $(5,56 \pm 0,50)$ бали. При всіх варіантах клінічних симптомокомплексів спостерігався значний регрес вогнищевих симптомів на 7-му та 14-ту доби захворювання, що свідчило про добрий прогноз ЛІ. На 7-му і 14-ту доби встановлено достовірне $(p<0,05)$ зменшення тяжкості ЛІ, що склало $(5,80 \pm 0,41)$ та $(4,27 \pm 0,50)$ бали відповідно.

Аналіз МРТ-даних показав, що у більшості хворих - 94 (77,0 \%) - лакунарні вогнища були множинними, незважаючи на перший епізод гострого порушення мозкового кровообігу. Отримані дані вказують на попереднє існування уражень дрібних перфоруючих артерій, перебіг яких був «німим», без клінічно маніфестаці. Одиничні вогнища візуалізувались тільки у 27 (22,1\%) хворих. Аналіз локалізаці ЛІ в різних структурах мозку показав, що найчастіше уражалися глибокі відділи біло речовини лобно частки - у 91 (74,6 \%) хворих та тім'яно частки - у $49(40,2 \%)$ хворих. ЛІ в білій речовині скронево частки спостерігалися в поодиноких випадках та не виявлялися в білій речовині потилично частки. ЛІ в ділянці внутрішньо капсули спостерігалися у $29(23,8 \%)$ хворих, із них переважали вогнища в ділянці заднього стегна - у 19 (15,6 \%) хворих. Серед підкіркових сірих утворень частіше уражалися шкаралупа - 20 (16,4\%), бліда куля 17 $(13,9 \%)$, хвостате ядро $13(10,7 \%)$. У більшості випадків ЛІ в цих утвореннях були множинні та $\mathrm{x}$ розміри не перевищували 10 мм. ЛІ в ділянці зорового горба спостерігались у 20 (24,6 \%) хворих та мали більші розміри. ЛІ в ділянці стовбура мозку найчастіше візуалізувалися в ділянці варолієва моста - у 25 (20,5\%) хворих, у 5 (4,1\%) - в ніжці мозку, у довгастому мозку лакунарні вогнища не спостерігались.

Морфометричні показники серця оцінювали за допомогою ЕхоДКГ на апараті «Biomedica» (Японія) згідно з рекомендаціями ASE, 1997. Визначали: товщину задньо стінки лівого шлуночка (ТЗСЛШ) та міжшлуночково перегородки (ТМШП); кінцевосистолічний і кінцеводіастолічний розміри ЛШ. У В-контрольованому М-режимі отримано розрахункові показники: Фракцію викиду (ФВ) за Simpson, кінцевий систолічний і діастолічний об'єми ЛШ, відносну товщину міокарда (ВTM), масу міокарда лівого шлуночка (ММЛШ) за формулою ASE. ІММЛШ визначали як співвідношення ММЛШ до площі поверхні тіла за формулою D. Dubois. За верхню межу норми IMМЛШ були вибрані величини, рекомендовані Європейським товариством кардіологів і Європейським товариством 3 гіпер-

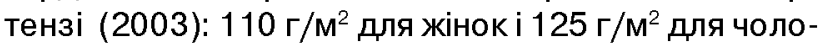
віків. За результатами ЕхоДКГ з урахуванням значень IMМЛШі ВТМ ЛШ визначали тип геометрі ЛШ. За формулами, запропонованими у посібниках з ехокардіографі, розраховано показники центрально гемодинаміки: УО, ХОК, серцевий індекс (Cl) [1].

Діастолічну дисфункцію ЛШ оцінювали за показниками трансмітрального діастолічного кровотоку: інтеграл лінійно швидкості кровотоку раннього діастолічного наповнення - E (см), швидкість кровотоку в систолу лівого передсердя (A), час ізоволюмічно релаксаці ЛШ (IVRT); та в режимі імпульснохвильового тканинного доплера на рівні мітрального фіброзного кільця: швидкість раннього наповнення - Ve, швидкість пізнього наповнення - Va, співвідношення е/а та Е/е. Враховувалися також фізіологічні чинники, які впливають на діастолічну дисфункцію, а саме вік, частота серцевих скорочень, систолічна функція ЛШ, функція передсердь. Контрольну групу (КГ) склали 42 особи, репрезентативні за віком та статтю по відношенню до хворих з ЛІ.

Статистичну обробку отриманих результатів виконано у відділі статистичних досліджень ДВНЗ «Тернопільський державний медичний університет» в програмному пакеті Statsoft Statistica. Порівняння вибірок здійснено із застосуванням критерію Стьюдента (t) та коефіцієнту кореляці Пірсона (r).

Результати й обговорення. Аналіз морфометричних показників серця показав, що у хворих з ЛІ спостерігається достовірно більша товщина ЗСЛШ та МШП, порівняно з КГ ( $p<0,05)$. Гіпертрофія ЛШ та МШП виявлена у 109 (89,3\%) хворих 3 даним підтипом II, причому у 32 (26,2 \%) товщина ЗСЛШ склала більше 1,40 см. КДР ЛШ становив $(4,84 \pm 0,11) \mathrm{cm}, \mathrm{KCP}-(3,20 \pm 0,11) \mathrm{cm}$. У більшості (107 (87,7 \%)) хворих з ЛІ порожнина ЛШбула нормальних розмірів і лише у 15 (12,3 \%) - дилатованою. КДО ЛШ становив $(112,78 \pm 3,74)$ мл, КСО $(44,71 \pm 8,32)$ мл.

Розширення ПШ спостерігалося у 12 (9,8 \%) хворих. У $18(14,7$ \%) виявлена гіпертрофія стінки ПШ. В середньому товщина стінки ПШ становила $(0,47 \pm 0,02)$ см. Ще у $9(7,4 \%)$ пацієнтів діагностовано розширення порожнини ПП. У $23(18,9 \%)$ хворих виявлено збільшені розміри ЛП (понад 4,0 см). У хворих з ЛІ ФВ склала $(59,84 \pm 1,29) \%$ та достовірно не відрізнялася від показників КГ. У $107(87,7 \%)$ ФВ становила більше $55 \%$ і лише у 15 (12,3 \%) ФВ була нижче $55 \%$.

Зони локального гіпокінезу в МШП та Зслш виявлено у 12 (9,8 \%) хворих. Дифузний гіпокінез зі зниженою глобальною скоротливою здатністю ЛШ відмічався у 7 (5,7 \%) пацієнтів. Систолодіастолічна дисфункція виявлена 4 (3,3 \%) хворих. Відносна товщина міокарда ЛШ становила $(0,55 \pm 0,02)$ і була достовірно вищою, ніж у КГ $(p<0,05)$. У $104(85,2$ \%) ВТ ЛШ була більшою, ніж 0,45 . 
Оеляди літератури, оригінальні дослідження, поеляд на проблему

Таблиця 1. Морфометричні показники серця у гострому періоді ЛІ

\begin{tabular}{|c|c|c|c|c|}
\hline Показник & $\mathrm{K} \Gamma$ & Mean & Minimum & Maximum \\
\hline ЛШ систола, см & $1,13 \pm 0,03$ & $1,30 \pm 0,04 *$ & 1,00 & 2,09 \\
\hline МШП систола, см & $1,14 \pm 0,02$ & $1,38 \pm 0,04 *$ & 0,96 & 2,10 \\
\hline $\begin{array}{l}\text { Передньо-задній } \\
\text { розмір ПШ, см }\end{array}$ & $2,22 \pm 0,07$ & $2,27 \pm 0,09$ & 1,60 & 3,67 \\
\hline ЛП, см & $3,73 \pm 0,08$ & $3,77 \pm 0,10$ & 2,50 & 4,90 \\
\hline ПП, см & $3,28 \pm 0,07$ & $3,25 \pm 0,11$ & 2,60 & 4,20 \\
\hline КДР, cм & $4,95 \pm 0,10$ & $4,84 \pm 0,11$ & 3,64 & 6,20 \\
\hline КДО, мл & $119,25 \pm 4,95$ & $112,78 \pm 3,74$ & 55,90 & 194,00 \\
\hline КСР, $\mathrm{CM}$ & $3,31 \pm 0,09$ & $3,20 \pm 0,11$ & 2,00 & 4,30 \\
\hline КСО, мл & $44,86 \pm 3,19$ & $44,71 \pm 8,32$ & 12,90 & 83,00 \\
\hline Аорта, см & $3,41 \pm 0,04$ & $3,32 \pm 0,07$ & 2,50 & 4,23 \\
\hline$\Phi \mathrm{B}, \%$ & $62,21 \pm 1,08$ & $59,84 \pm 1,29$ & 45,00 & 72,00 \\
\hline УО, мл & $76,05 \pm 3,21$ & $69,94 \pm 5,13$ & 17,70 & 122,90 \\
\hline ХОК, л $\times$ Хв & $5,51 \pm 0,19$ & $4,66 \pm 0,36^{*}$ & 1,40 & 9,10 \\
\hline BTM, у. о. & $0,47 \pm 0,02$ & $0,55 \pm 0,02 *$ & 0,35 & 0,95 \\
\hline ММЛШ, г & $251,80 \pm 16,25$ & $323,87 \pm 20,60^{*}$ & 174,20 & 722,30 \\
\hline IMМЛШ, г/м² & $132,68 \pm 6,15$ & $163,36 \pm 9,80^{*}$ & 87,10 & 344,00 \\
\hline $\mathrm{CI}, \mathrm{J} / \mathrm{XB} \cdot \mathrm{M}^{2}$ & $2,60 \pm 0,12$ & $2,37 \pm 0,17$ & 0,70 & 4,80 \\
\hline E/A & $1,10 \pm 0,10$ & $0,71 \pm 0,04^{*}$ & 0,30 & 1,00 \\
\hline E, cM & $0,84 \pm 0,14$ & $0,40 \pm 0,05^{*}$ & 0,63 & 0,10 \\
\hline $\mathrm{A}, \mathrm{cm}$ & $0,76 \pm 0,11$ & $0,58 \pm 0,04 *$ & 0,78 & 0,22 \\
\hline
\end{tabular}

Примітка. * - показники достовірно відрізняються від КГ $(\mathrm{p}<0,05)$.

ММЛШ склала $(323,87 \pm 20,60)$ г, а індекс маси міокарда ЛШ - $(163,36 \pm 9,80) \Gamma / \mathrm{m}^{2}$. ММЛШ та ІММЛШ були достовірно вищими, порівняно з КГ $(p<0,05)$. Нормальна геометрія серця спостерігалася лише у $17(13,9 \%)$ хворих, у інших $105(86,1 \%)$ виявлено патологічне ремоделювання ЛШ. У КГ нормальне ремоделювання ЛШ мало місце у $71,4 \%$. Концентрична гіпертрофія діагностована у $96(76,6 \%)$, ексцентрична гіпертрофія - у 10 $(8,2 \%)$ та концентричне ремоделювання ЛШ - у 9 $(7,4 \%)$ хворих з ЛІ. Показники УО та ХОК в середньому у пацієнтів з ЛІ достовірно не відрізнялися від значень КГ. УО становив $(69,94 \pm 5,13)$ мл, проте у $15(12,3 \%)$ з ЛІ з вираженою гіпертрофією ЛШ УО був менше 30 мл. Середні значення ХОК склали $(4,66 \pm 0,36)$ л·Хв, $\mathrm{Cl}-(2,37 \pm 0,17)$ л/ХВ' $\mathrm{M}^{2}$. ЛІ виникав переважно на фоні гіпокінетичного типу центрально гемодинаміки, який ми спостерігали у 82 $(67,2 \%)$ хворих. В інших 40 (32,8 \%) пацієнтів виявлено еукінетичний тип гемодинаміки.

Для хворих з ЛІ на ґрунті ГХ була характерна діастолічна дисфункція ЛШ з порушенням його релаксаці, що виявлялася у 106 (86,9 \%) випадках. Iнтеграл лінійно швидкості кровотоку раннього діастолічного наповнення (Е) становив $(0,40 \pm 0,05) \mathrm{cm}$, швидкість кровотоку в систолу лівого передсердя (A) - $(0,58 \pm 0,04)$ см. Значення $\mathrm{E}$ та А у пацієнтів з ЛІ достовірно відрізнялися від показників КГ $(p<0,05)$. Співвідношення Е/А в середньому склали $(0,71 \pm 0,04)$ і були достовірно нижчими, порівняно з КГ $(p<0,05)$. Нами виявлено достовірно нижчі величини індексу
$\mathrm{Ve} / \mathrm{Na}$ по відношенню до значень КГ, які становили відповідно $(0,49 \pm 0,03)$ та $(0,92 \pm 0,05)(p<0,05)$.

Порівняльний аналіз морфометричних показників серця у хворих з ЛІ двох вікових груп засвідчив залежність деяких параметрів від віку пацієнтів (табл. 2).

Встановлено, що у хворих 45-50 р. ЛІ виникає на фоні більш виражено гіпертрофі ЛШ, порівняно 3 пацієнтами старше 60 р. Виявлено достовірно більшу товщину ЗСЛШта МШП та більшу ВТМ ЛШу хворих молодшо віково групи, порівняно з хворими старше 60 p. $(p<0,05)$. Такожу пацієнтів 45-60 p. спостерігався достовірно вищий ІММЛШ $(\mathrm{p}<0,05)$. Достовірно різниці між іншими морфометричними показниками серця у хворих з ЛІ різних вікових груп нами не виявлено. У хворих старшо віково групи виявлено вищі значення параметрів центрально гемодинаміки (УO, XOK, Cl) у порівнянні з молодшими пацієнтами, проте достовірна відмінність спостерігалася лише між значеннями XOK $(p<0,05)$. Отримані дані можуть вказувати на більші компенсаторні механізми мозково ауторегуляці у хворих 45-60 р. при ГХ, коли ЛІ виникає на фоні значніших порушень морфометричних показників серця (гіпертрофі ЛШ та патологічного ремоделювання). 3 іншого боку, менш виражена гіпертрофія ЛШ у хворих з ЛІ старше 60 р. може бути пов'язана 3 меншою важкістю інсульту у даній віковій групі.

У хворих молодшо віково групи виявлено достовірно вищі значення $\mathrm{Ve} / \mathrm{Na}-0,53 \pm 0,04$ по відношенню до пацієнтів старше 60 р. $-(0,44 \pm 0,03)$. 
Оеляди літератури, ориаінальні дослідження, поеляд на проблему

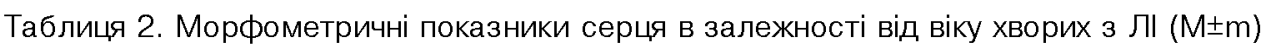

\begin{tabular}{|c|c|c|}
\hline \multirow{2}{*}{ Показник } & \multicolumn{2}{|c|}{ Вік хворих } \\
\hline & $45-60$ p. $(n=65)$ & старше 60 р. $(\mathbf{n}=57)$ \\
\hline ЛШ систола, см & $1,31 \pm 0,04$ & $1,21 \pm 0,04 *$ \\
\hline МШП систола, см & $1,43 \pm 0,05$ & $1,27 \pm 0,06^{*}$ \\
\hline Передньо-задній розмір ПШ, см & $2,17 \pm 0,10$ & $2,34 \pm 0,18$ \\
\hline ЛП, см & $3,70 \pm 0,12$ & $3,86 \pm 0,16$ \\
\hline КДР, $\mathrm{cM}$ & $4,77 \pm 0,12$ & $4,94 \pm 0,24$ \\
\hline КДО, мл & $108,06 \pm 6,55$ & $120,00 \pm 9,30$ \\
\hline KCP, cM & $3,15 \pm 0,12$ & $3,14 \pm 0,28$ \\
\hline КСО, мл & $40,89 \pm 3,86$ & $46,62 \pm 5,46$ \\
\hline Аорта, см & $3,31 \pm 0,09$ & $3,42 \pm 0,08$ \\
\hline$\Phi B, \%$ & $60,96 \pm 1,51$ & $59,10 \pm 3,21$ \\
\hline УО, мл & $66,24 \pm 5,13$ & $74,68 \pm 8,08$ \\
\hline ХОК, л·хв & $4,34 \pm 0,28$ & $4,86 \pm 0,32 *$ \\
\hline BTM, у. о. & $0,57 \pm 0,02$ & $0,51 \pm 0,03^{*}$ \\
\hline ММЛШ, г & $333,95 \pm 23,31$ & $292,07 \pm 22,31$ \\
\hline IMМЛШ, $\Gamma / \mathbf{M}^{2}$ & $169,12 \pm 8,67$ & $150,41 \pm 9,91^{*}$ \\
\hline $\mathrm{CI}, \mathrm{\pi} / \mathrm{XB}^{*} \mathrm{M}^{2}$ & $2,26 \pm 0,15$ & $2,47 \pm 0,17$ \\
\hline $\mathrm{E} / \mathrm{A}$ & $0,72 \pm 0,04$ & $0,70 \pm 0,03$ \\
\hline
\end{tabular}

Примітка. * - показники достовірні по відношенню до значень хворих з ЛІ віком 45-60 p. $(p<0,05)$.

Встановлена залежність деяких морфометричних показників серця та показників центрально гемодинаміки від тяжкості ЛІ (табл. 3).

У пацієнтів з тяжким ЛІ, порівняно з хворими з легким II, була достовірно більша товщина ЗСлш та МШП ( $<<0,05)$, що свідчило про більш тривалу ГХ. Також у хворих з тяжким ЛІ відмічалися достовірно більші розміри ЛП та передньо-задній розмір ПШ, порівняно з легким та ЛІ середнього ступеня тяжкості $(p<0,05)$. При тяжкому II достовірно знижувалася $Ф \mathrm{~B}$, порівняно з хворими із легким та се- редньотяжким ЛІ $(p<0,05)$. У всіх пацієнтів з тяжким ЛІ ФВ становила менше $55 \%$. Під час гостро фази інсульту судини головного мозку, відповідальні за перфузію ішемічно напівтіні, втрачають ауторегуляторну функцію, що вимагає збільшення серцевого викиду для підтримки мозкового кровотоку до ішемізовано ділянки. У той же час знижена ФВ ЛШ в умовах гострого інсульту може привести до поглиблення неврологічного дефіциту та погіршання функціонального результату після інсульту [5].

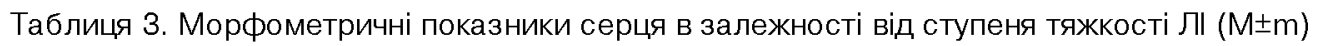

\begin{tabular}{|c|c|c|c|}
\hline \multirow[b]{2}{*}{ Показник } & \multicolumn{3}{|c|}{ Тяжкість ЛІ } \\
\hline & $\begin{array}{l}\text { легкий } \\
(\mathrm{n}=45)\end{array}$ & $\begin{array}{c}\text { середньотяжкий } \\
(\mathrm{n}=70)\end{array}$ & $\begin{array}{c}\text { тяжкий } \\
(\mathrm{n}=7)\end{array}$ \\
\hline ЛШ систола, см & $1,24 \pm 0,05$ & $1.31 \pm 0.05$ & $1,42 \pm 0,04 *$ \\
\hline МШП систола, см & $1,33 \pm 0,06$ & $1,42 \pm 0,05$ & $1,46 \pm 0,06^{*}$ \\
\hline Передньо-задній розмір ПШ, см & $2,30 \pm 0,15$ & $2,14 \pm 0,09$ & $2,81 \pm 0,17 *$ \\
\hline ЛП, см & $3,81 \pm 0,09$ & $3,70 \pm 0,15$ & $4,32 \pm 0,16^{*}$ \\
\hline КДР, см & $4,87 \pm 0,17$ & $4.79 \pm 0.15$ & $5,04 \pm 0,20$ \\
\hline КДО, мл & $114,79 \pm 8,67$ & $109,16 \pm 8,38$ & $120,00 \pm 9,30$ \\
\hline КСР, см & $3,17 \pm 0,21$ & $3,16 \pm 0,20$ & $3,76 \pm 0,25 *$ \\
\hline КСО, мл & $45,81 \pm 6,83$ & $41,92 \pm 4,70$ & $50.40 \pm 4.86$ \\
\hline Аорта, см & $3,43 \pm 0,19$ & $3,23 \pm 0,13$ & $3,63 \pm 0,15$ \\
\hline$\Phi B, \%$ & $59,19 \pm 2,56$ & $61,65 \pm 1,32$ & $52,12 \pm 2,65^{*}$ \\
\hline УО, мл & $68,46 \pm 9,52$ & $68,84 \pm 5,67$ & $59,60 \pm 6,85$ \\
\hline $\mathrm{XOK,} \mathrm{л'хв}$ & $4,40 \pm 0,56$ & $4,72 \pm 0,44$ & $4,10 \pm 0,51$ \\
\hline BTM, у. о. & $0,54 \pm 0,03$ & $0,56 \pm 0,03$ & $0,56 \pm 0,02$ \\
\hline ММЛШ, г & $320,17 \pm 23,52$ & $323,46 \pm 21,44$ & $369,57 \pm 19,64$ \\
\hline 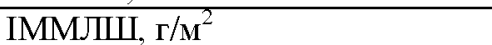 & $161,13 \pm 8,05$ & $164,41 \pm 11,31$ & $172,29 \pm 7,87$ \\
\hline $\mathrm{CI}, \mathrm{I} / \mathrm{XB} \cdot \mathrm{M}^{2}$ & $2,23 \pm 0,09$ & $2,43 \pm 0,21$ & $2,00 \pm 0,10^{*}$ \\
\hline $\mathrm{E} / \mathrm{A}$ & $0,66 \pm 0,09$ & $0,73 \pm 0,03$ & $0,65 \pm 0,06$ \\
\hline
\end{tabular}

Примітка. * - показники достовірні по відношенню до значень хворих з легким ЛІ $(p<0,05)$. 
Оеляди літератури, оригінальні дослідження, поеляд на проблему

При тяжкому ЛІ виявлялися достовірно нижчі показники Cl (у всіх пацієнтів дано групи спостерігався гіпокінетичний тип гемодинаміки) $(p<0,05)$.

Проведений кореляційний аналіз не виявив достовірного кореляційного зв'язку між тяжкістю ЛІ у гострому періоді та морфометричними показниками серця. Виявлено достовірну кореляційну залежність між е/а та тяжкістю ЛІ на 1-шу добу II ( $r=-0,565, p=0,045)$.

Висновки. 1. ЛІ виникає на фоні порушення морфометричних показників серця: помірно та виражено гіпертрофі ЛШ (у 89,3 \%), патологічного

\section{ЛІТЕРАТУРА}

1. Струтынский А. В. Эхокардиография. Анамнез и интерпретация / А. В. Струтынский. - М. : МЕДпрессинформ, 2001. - 204 с.

2. Cerebral vasomotor reactivity of patients with acute ischemic stroke: cortical versus subcortical infarcts: an IsraeliTurkish collaborative study / A. Y. Gur, D. Gbcbyener, N. bzbner [et al.] // Journal of the Neurological Sciences. - 2007. Vol. 257. - P. 121-125.

3. Jackson G. Are lacunar strokes really different? A systemic review of differences in risk factor profiles between lacunar and nonlacunar strokes / G. Jackson // Stoke. 2005. - Vol. 36 (4). - P. 891-901.

4. Low Left Ventricular Ejection Fraction in Patients with Acute Ischemic Stroke May Be Predictive of Poor Functional Outcome (P03.199) / T. Mathias, K. Albright, T. Beasley [et al.] // Neurology. - 2013. - Vol. 12. ремоделювання ЛШ (у 86,1 \%) переважно у вигляді концентрично гіпертрофі ЛШ - у 96 (76,6 \%) хворих. У 86,9 \% пацієнтів спостерігалися ознаки діастолічно дисфункці ЛШза гіпертрофічним типом.

2. Встановлена залежність деяких морфометричних показників від тяжкості ЛІ: при тяжких ЛІ виявлено достовірно більший ступінь гіпертрофі ЛШ, більші розміри ЛП та достовірно нижчу ФВ та $\mathrm{Cl}$, порівняно з пацієнтами з легким та середньотяжким ЛІ.

3. У пацієнтів віком 45-60 р. ЛІ виникає на фоні більш виражено гіпертрофі ЛШ.

5. Pantoni L. Cerebral small vessel disease: from pathogenesis and clinical characteristics to therapeutic challenges / L. Pantoni // The Lancet Neurology. - 2010. Vol. $9(7)$. - P. 689-701.

6. Progressive lacunar stroke: Review of mechanis, prognostic features and putative treatment / A. Del. Bene, V. Palumbo, M. Lamossa [et al.] // International Journal of Stroke. - 2012. - Vol. 7, Issue 4. - P. 321-329.

7. Significance of Haemodynamic and Haemostatic Factors in the Course of Different Manifestations of Cerebral Small Vessel Disease: The SHEF-CSVD Study-Study Rationale and Protocol / J. Staszewski, R. Piusicska-Macoch, E. Skrobowska / / Neuroscience Journal. - 2013. - Vol. 2013, Article ID 424695, 9 pages http://dx.doi.org/10.1155/2013/424695.

8. Silent cerebral matter lesions in middle-aged essential hypertensive patients / C. Sierra, A. Sierra, Mercader [et al.] // J. Hypertens, - 2002. - Vol. 20. - P. 519-524.

\title{
MORPHOMETRIC HEART PARAMETERS IN ACUTE PERIOD OF LACUNAR STROKE ○N. R. Sokhor
}

\author{
SHEI «Ternopil State Medical University by I. Ya. Horbachevsky of MPH of Ukraine»
}

SUMMARY. In 122 patients with lacunar stroke (LS) were analyzed morphometric parameters of the heart and central hemodynamics. It was observed that LS is characterized by moderate and severe LVH (at $89.3 \%$ ), pathological LV remodeling (at $86.1 \%$ ) mainly in the form of concentric LVH - (to $76.6 \%$ ), left ventricular diastolic dysfunction by hypertrophic type (in $86.9 \%$ ) patients. There was dependent between morphometric parameters of the heart and severity of LS: in severe LS was significantly greater degree of LV hypertrophy, size of left atrium and significantly lower ejection fraction and heart index compared with patients with mild and moderate severity of LS.

KEYWORDS: lacunar stroke, morphometric heart parameters, central hemodynamics.

Отримано 27.02.2015 